Proceedings of the 2018 International Scientific Conference 'Economic Sciences for Agribusiness and Rural Economy' No 1, Warsaw, 7-8 June 2018, pp. 40-47

\title{
ENVIRONMENTAL SUSTAINABILITY IN AGRICULTURE: DIFFERENT WAYS OF QUANTIFICATION
}

\author{
Bazyli Czyżewski, PhD, Associate Professor'; Anna Matuszczak, PhD, Associate \\ Professor ${ }^{2}$; Andrea Muntean, PhD, Associate Professor ${ }^{3}$ \\ ${ }^{1,2}$ Faculty of Economics, Poznań University of Economics and Business \\ ${ }^{3}$ Faculty of Economic Sciences, '1 Decembrie 1918' University of Alba lulia
}

\begin{abstract}
The main goal of the article is to compare three approaches to measuring environmental sustainability in agriculture: (1) environmental burden index, (2) sustainable value of eco-efficient production and (3) sustainable value of eco-effective farm, applied by the authors to the sample of 125 EUFADN regions in 2015. The study indicate a fundamental problem: the notion of environmental sustainability in agriculture differs depending on the criterion we apply. The authors recognized a principle trade-off in CAP which consist of compensating strain on the natural environment with production or with public goods provision. The choice between these two effects is crucial to draw a consistent development path for the Common Agricultural Policy.
\end{abstract}

Keywords: environmental burden, eco-efficiency, eco-effectiveness, sustainable development, agriculture, EU regions

JEL codes: Q01, Q56, J43, O13

\section{INTRODUCTION}

Discussions on the sustainable development of agriculture, the methods and measurement indicators, evaluation and indicative values, etc. are nothing new (Kates et al., 2005; Zegar, 2012). In the literature, the issue is most often analysed in its economic, social and environmental aspects. While the first two are not difficult to measure and evaluate (mostly from the perspective of income, employment, education), some dilemmas arise in the context of environmental sustainability. One of the major dilemmas, if not the most important, is whether (1) to decrease the overall environmental burden of agriculture no matter production effects, (2) to generate the highest production in relation to the polluting means used (e.g. fertilisers, plant protection products) and gases emitted (e.g. greenhouse gases) during production (eco-efficiency), or (3) to adopt a consensus consisting in the fact that the products used in agricultural production are

${ }^{1}$ Corresponding author: al. Niepodległości 10,61-875 Poznań, Poland, bazyli.czyzewski@ue.poznan.pl, +4861 8543017

${ }^{2}$ Corresponding author: al. Niepodległości 10,61-875 Poznań, Poland, anna.matuszczak@ue.poznan.pl, +4861 8543017

${ }^{3}$ Corresponding author: Strada Gabriel Bethlen 5, Alba Iulia 510009, Romania, bologandreea@gmail.com, +40 258806130 
unfavourable for the natural environment, so simultaneously shall be compensated through agri-environmental activities, which create environmental public goods (eco-effectiveness). Unfortunately, there is no universally accepted research methodology however, the eco-efficiency approach (2) is dominant in the literature. The aim of the article is to compare three approaches to measuring environmental sustainability: (1) environmental burden index for agriculture, (2) sustainable value of eco-efficient production and (3) sustainable value of eco-effective farm, applied to the sample of EUFADN regions in 2015.

\section{THEORETICAL BACKGROUND}

\section{Synthetic measure of environmental burden in agriculture}

The construction of a synthetic measure of environmental burden in agriculture is a problematic issue. Reytar, Hanson and Henninger (2014) point out 25 various indicators related to environmental sustainability. Variables referring to water consumption, agricultural subsidies, climate change, agricultural production, ecosystem biodiversity, and land use were deemed to be of key significance.

According to the OECD (2001), in turn, environmental indicators for agriculture should include water and soil quality, biodiversity, greenhouse gas emissions, land conservation, wildlife habitats, and landscape. Zhen and Routray (2003) specify the measurement of farm sustainability in the environmental aspect, bringing it down to two areas: water management and arable farming structure. The authors cited here proposed the following measures: amount of fertilisers/pesticides used per unit of agricultural land, amount of irrigation water used per unit of agricultural land, soil nutrient content, depth of groundwater table, quality of groundwater for irrigation, water use efficiency, nitrate content of groundwater and crops. Other approaches point to the issues of pesticide, herbicide, and fungicide use in agricultural production, the use of organic fertilisers, the use of synthetic fertilisers and plant protection products or crop rotation (Saltiel, Baunder and Palakovich, 1994; Hayati and Karami, 1996; JEPE, 2018). Studies on Dutch or Danish agriculture, reveal that high stock density (particularly in the case of poultry, cattle, and pigs) per ha of agricultural land (AL) does not create favourable conditions for environmental sustainability due to relatively high emissions of nitrogen or phosphorus compounds or carbon oxides (European Commission, 2000).

\section{A concept of eco-efficient production}

The term 'eco-efficiency' appeared in the 1990s as a practical tool to measure sustainability. It was introduced by the World Business Council for Sustainable Development in 2000 to identify a management philosophy aimed at encouraging businesses to search for environmental improvements that yield parallel economic benefits. In other words, companies are asked to be more environmentally responsible and more profitable. The OECD (1998) refers to ecoefficiency as the efficiency with which ecological resources are used to meet human needs, which can be measured as the ratio of an output divided by an input, where the output is expressed by the value of products and services produced by a firm, sector or economy as a whole, while the input is the sum of environmental pressures generated by the firm, the sector or the economy. Therefore, an output increase, for a given level of inputs, or an input decrease, for a given level of outputs, leads to an improvement of eco-efficiency. However, does a change in eco-efficiency reflect a corresponding change in terms of overall sustainability, since what this ratio measures is only the relative level of environmental pressure in relation to the volume of economic activity? (Bonfiglio, Arzeni and Bodini, 2017) In the authors' opinion sustainability is more related to absolute levels of environmental pressure (Czyżewski, Matuszczak and Muntean, 2018).

\section{Eco-effective versus eco-efficient}

As aforementioned, the eco-efficiency approach may be somewhat contradictory to the idea of environmental sustainability, which should take into consideration the actual environmental effect in farms. In addition, the common agricultural policy is evolving and, next to its original assumptions related to the assurance of quantitative and qualitative food safety, support for agricultural incomes etc., 
sets goals related to the respect for the environment or the creation of public goods, in particular environmental. Therefore, it is interesting to what degree the support for agriculture, from various CAP programmes, national and regional policies, affects the increase in eco-efficiency of farms and to what extent is affects their eco-effectiveness. At this point a certain conflict between eco-effectiveness and ecoefficiency might be expected, as the programmes supporting agriculture surely include such that have a strong impact on eco-efficiency issues, but also such wherein eco-effectiveness will be dominant. This conflict impedes the sustainable development of agriculture. The results of this research, then, will contribute to the discussion regarding the future of the EU's common agricultural policy after 2020, but also the national and regional agricultural and environmental policies in the context of its evolution. The crucial questions is what should be the output measure in the input-output (I-O) approaches used to assess the environmental sustainability? It is also not certain to what extent the hitherto funding of agriculture facilitates the implementation of goals regarding its sustainable development, and to what extent it consolidates the industrial model of production, where issues of efficiency will be of key importance.

\section{MATERIALS AND METHODS}

\section{Synthetic measure of environmental burden in agriculture}

Taking into account above-mentioned remarks, the following variables from the EU FADN database may be used and actually were applied in our study for the construction of a synthetic measure (EUFADN codes in brackets):

- stock density per 1 ha (SE120);

- fertiliser use intensity in crop production (SE295/ /SE136);

- plant protection product use (SE300/SE136);

- total production energy intensity (SE345/SE131);

- woodland area per 1 ha of AL (SE075/SE025).

The above set of variables fits in with the discussion on the environmental sustainability of agriculture relatively well represented in the literature
(Latruffe et al., 2016). The indicators were converted into stimulants. Synthetic measures of the environmental sustainability for an average farm in a region is in this study determined by Hellwig's method (Poczta-Wajda and Poczta, 2016), but a choice of possible methods is very wide here. We also recommend TOPSIS-CRITIC method (Czyżewski and Kryszak, 2017). Hellwig's method consist of the following procedure: the distance from the pattern was determined for each object $P_{i}$ (region), cf. formula (1):

$$
d_{i}=1-\frac{D_{i 0}}{D_{0}}(i=1,2, \ldots, n)
$$

where:

$D_{i 0}$ - the distance of the $i$-th object from $P_{0}$; $x_{i j}$-are the empirical values in the I th region.

$$
\begin{gathered}
D_{i 0}=\sqrt{\sum_{j=1}^{m}\left(z_{i j}-z_{o j}\right)^{2}} \\
z_{i j}=\frac{x_{i j}-\min _{x_{i j}}}{\max _{x_{i j}}-\min _{x_{i j}}}
\end{gathered}
$$

\section{Sustainable value of eco-efficient production}

Estimating sustainable value with frontier benchmarking (ESV, authors' original methodology) was carried out assuming a trade-off of productivity versus environment. Environmental Sustainable Value (ESV) is a value-oriented method, developed as a means of measuring agricultural eco-efficiency at microeconomic level (e.g agricultural farm). This enables a synthetic assessment of a farm's contribution to farming sustainability, taking into account the efficiency resulting from using economic, social and environmental resources in comparison to the opportunity cost (Figge and Hahn, 2005; Van Passel et al., 2007; Illge Hahn and Figge, 2008; Burja and Burja, 2016). In the authors opinion ESV has many advantages comparing to the standard DEA approach, since it also measures the monetary value of 'contribution to the sustainability' that should be borne to achieve it or was paid in surplus. Thus, it gives much more information useful for policymakers than a linear ordering. However, the authors propose to 
engage DEA technic to identify a benchmark unit for ESV. In the literature, the use of DEA techniques to measure eco-efficiency in different sectors, as well as for the assessment of the environmental performance of farms and the agricultural sector, is widely known (Gadanakis et al., 2015). Conversely, there are not so many studies which estimate eco-efficiency at farm level using the DEA approach (Picazo-Tadeo Gómez-Limón and Reig-Martínez, 2011; GómezLimón et al., 2012; Picazo-Tadeo et al., 2012; Berre et al., 2015; Gadanakis et al., 2015; Pérez Urdiales, Lansink and Wall, 2016).

The calculation formula for determining the ESV of the farms in regions is as follows:

$$
S V_{i}=\frac{1}{m} \sum_{j=1}^{m} r_{i j}\left(\frac{y_{i j}}{r_{i j}}-\frac{y b_{i j}}{r b_{i j}}\right)
$$

where:

$S V_{i} \quad$ - sustainable value afferent to a farm from region $i$;

$r_{i j}, r b_{i j}-$ resource quantity of type $j$ and region $i$ of the analysed farm, i.e. of the farm considered as reference system;

$y_{i j}, y b_{i j}$ - return of resources of the analysed and benchmark farm;

$i=1, \ldots, n-$ region;

$j=1, \ldots, m-$ type of analysed resource.

Through its contents, SV indicates the absolute size of the value created in a sustainable manner by the agricultural farms of various countries of the EU. To take into account the size effects and to make comparisons between farms of various countries, we can calculate the indicator Return to cost ratio $\left(R T C_{i}\right)$. This one shows the relative contribution of farms from various countries to the sustainable performance compared to the benchmark:

$$
R T C_{i}=\frac{y_{i}}{y_{i}-S V_{i}}
$$

where:

$y_{i}$ - created output;

$S V_{i}$ - sustainable value of the average agricultural farm of country $i$.
The advantage associated with the use of DEA in measuring eco-efficiency or eco-effectiveness for ESV indicator is the identification of a set of optimal weights for inputs $(r)$ determined at farm level which maximize the eco-efficiency or eco-effectiveness score relative to the other farms in the sample. Optimizing formula used to identify benchmark units is orientated as follows, for the eco-efficiency:

$$
\max _{r} O U T=\frac{\sum_{k=1}^{n} y_{i j}}{\sum_{j=1}^{m} r_{i j}}
$$

and for the eco-effectiveness (due to the constant resources of public goods):

$$
\min _{y} I N P=\frac{\sum_{k=1}^{n} y_{i j}}{\sum_{j=1}^{m} r_{i j}}
$$

where:

$O U T$ - output indicator;

$I N P$ - input indicator;

$y_{i j} \quad-$ output $j$ of a farm $i$;

$r_{i j} \quad-$ value of polluting capital as input indicator; $k=1, \ldots, n-$ type of analysed output.

In the eco-efficiency approach as a trade-offs productivity versus environment we use the similar set of variables as described in the previous point: the input indicator will be polluting capitals (crop protection, fertilisers, energy, non-wood area, stocking density) and as an effect indicator - total output, including shares of total output crops and total output livestocks.

\section{Sustainable value of eco-effective farm}

In the second ecological approach we have employed environmental public goods as the effect indicator (y), assuming 'institutional' valuation of public goods by CAP subsidies (Czyżewski and Matuszczak, 2016; Czyżewski, Przekota and Poczta-Wajda, 2017; Czyżewski and Matuszczak, 2018). Hence, we used the same formulas (4)-(6), and the input indicator will be polluting capitals (as above) and as the effect indicator - environmental subsidies. 125 European regions (excluding the Canaries, Cyprus, Malta and Luxembourg - outliers) were analysed in 2015, as the 
last available year in FADN, since we are treating this as a pilot study.

\section{RESULTS AND DISCUSSION}

Based on the analyses carried out, three rankings of EU regions were made, classifying them according to the synthetic measure of environmental burden, ecoefficiency and eco-effectiveness of the agricultural activity conducted in the average farm in EUFADN region.

Only Italian regions and Austrian reoccur in three/ /two 'top 10' rankings (Table 1). However it is worth noting that the similarities of agrarian structures in the rankings concerns only 'environmental burden' and 'eco-effectiveness approach. This suggests that 'eco-efficiency' criterion tells us a completely different story. A majority of regions from the top eco-efficiency list (except Italian) doesn't appear among those which exert the lowest pressure on the environment or provide a sufficient value of public goods to compensate for polluting capital used. On the other hand, the low pressure on the environment means sometimes being very eco-inefficient - for instance Comunidad Valenciana (ESP) which is in the top 10 ' of the lowest environmental burden and simultaneously in the 'bottom 10' of the eco-efficiency. Meanwhile, Finnish regions appears as very eco-effective, but exerts however very big pressure on the environment (which is compensated by the public goods provision). The rankings of 'bottom 10' for the eco-efficiency and eco-effectiveness are much more similar then 'top 10s' while dominated by Romanian regions, which seems to be neither efficient in terms of production, nor effective in the provision of the environmental goods requested by CAP.

It was also observed that the most intensive European agriculture (Dutch, Danish, Belgian, French) enjoys the highest degree of environmental sustainability according to the eco-efficiency approach, where the effect is the total output value. A high position in this ranking means that agricultural producers from these regions achieve relatively the best ratio of the above-mentioned total output to the polluting capital input used. To put it differently, the productivity of the polluting capital (fertilisers, plant protec- tion products, energy, etc.) is relatively the highest in the case of farms from this group of EU regions. At the bottom of this ranking, there are also Greek regions close to the Romanian ones, being the least efficient in terms of eco-productivity. Table 1 also shows ESV, expressed in euros, brought in by farms from individual EU regions - for instance, the best French farms (from Provence-Alpes-Côte d'Azur region) or Dutch make as much as accordingly EUR 79,004 and 172,937 of surplus environmental sustainable value considered from the point of view of eco-efficiency. On the other hand, in the case of farms which are the weakest according to this criterion (Comunidad Valenciana), the value remains at a relatively high, negative level (EUR -248,037). It can therefore be assumed that the value reflects the level of inefficiency in the use of the polluting capital input relative to the total output achieved which may be balanced in this approach by the adequate growth in output. At the same time, when using eco-effectiveness approach, the amount can determine the value of environmental public goods which these farms should deliver in order to compensate for the negative effects of their activity.

Yet. the highest environmental sustainability according to the idea of eco-effectiveness, where the result is the amount of environmental subsidies obtained, can be observed in the case of agriculture which can be considered as extensive. This can be found in the Finnish, Swedish, Italian, and Austrian regions. On the opposite side, we find farms from regions which clearly do not participate in CAP's environmental scheme. Farms with a positive, relatively high ESV according to the eco-effectiveness criterion are characterized by lower use of fertilisers (eight times lower), plant protection products (more than twenty times lower), and energy (four times lower). Stock density seems not to be of much significance, yet it should be noted that in the case of these farms, there are five times higher relation of wooden area to utilized agricultural area (UAA). It can be said that the philosophy of the operation of farms achieving a high ESV level according to the eco-effectiveness criterion lies in the lowest possible strain on the natural environment, which clearly does not go hand in hand with the highest production results and which 
Table 1. Top and bottom 10 environmentally sustainable EU regions according to synthetic environmental burden measure, eco-efficient, and eco-effective approach, (benchmark units calculated using DEA, 125 EUFADN regions, 2015)

\begin{tabular}{|c|c|c|c|c|c|c|c|}
\hline \multicolumn{2}{|l|}{ Environmental burden } & \multicolumn{3}{|l|}{ Eco-efficiency } & \multicolumn{3}{|l|}{ Eco-effectiveness } \\
\hline Region & $\mathrm{H}$ & Region & RTC & $\begin{array}{c}\mathrm{SV} \\
(\mathrm{EUR})\end{array}$ & Region & RTC & $\begin{array}{c}\mathrm{SV} \\
(\mathrm{EUR})\end{array}$ \\
\hline \multicolumn{8}{|c|}{ Top 10} \\
\hline Alto Adige (ITA)* & 0.52 & $\begin{array}{l}\text { Provence-Alpes-Côte } \\
\text { d'Azur (FRA) }\end{array}$ & 1.69 & 79004 & Aosta (ITA) & 2.53 & 4100 \\
\hline Trentino (ITA) & 0.42 & the Netherlands (NED) & 1.65 & 172937 & Pohjois-Suomi (FIN) & 1.99 & 6221 \\
\hline Liguria (ITA) & 0.38 & Alto Adige (ITA) & 1.59 & 23687 & Etelä-Suomi (FIN) & 1.59 & 3808 \\
\hline Aosta (ITA) & 0.31 & $\begin{array}{l}\text { Languedoc-Roussillon } \\
\text { (FRA) }\end{array}$ & 1.45 & 42297 & Sisä-Suomi (FIN) & 1.53 & 2809 \\
\hline Slovenia (SVN) & 0.26 & Trentino (ITA) & 1.44 & 16883 & Austria (OST) & 1.45 & 1522 \\
\hline Calabria (ITA) & 0.24 & La Rioja (ESP) & 1.43 & 26426 & Pohjanmaa (FIN) & 1.38 & 2959 \\
\hline Toscana (ITA) & 0.24 & Toscana (ITA) & 1.39 & 22800 & Lan i norra (SVE) & 1.32 & 1739 \\
\hline $\begin{array}{l}\text { Comunidad Valenciana } \\
\text { (ESP) }\end{array}$ & 0.20 & Denmark (DEN) & 1.38 & 91343 & Cantabria (ESP) & 1.26 & 1245 \\
\hline $\begin{array}{l}\text { Ipiros-Peloponissos- } \\
\text { Nissi Ioniou (ELL) }\end{array}$ & 0.20 & Bretagne (FRA) & 1.38 & 77347 & $\begin{array}{l}\text { Skog ligger Mellskogs } \\
\text { (SVE) }\end{array}$ & 1.25 & 1694 \\
\hline Austria (OST) & 0.20 & Vlaanderen (BEL) & 1.38 & 75854 & $\begin{array}{l}\text { Alentejo i Algarve } \\
(\mathrm{POR})\end{array}$ & 1.07 & 202 \\
\hline \multicolumn{8}{|c|}{ Bottom 10} \\
\hline Thueringen (DEU) & 0.089 & Centru (ROU) & 0.61 & -7285 & $\begin{array}{l}\text { Małopolska and Pogórze } \\
(\mathrm{POL})\end{array}$ & 0.006 & -2759 \\
\hline $\begin{array}{l}\text { Severen tsentralen } \\
(\mathrm{BGR})\end{array}$ & 0.089 & Thessalia (ELL) & 0.61 & -14996 & Nord-Vest (ROU) & 0.005 & -2791 \\
\hline Severozapaden (BGR) & 0.088 & Nord-Est (ROU) & 0.61 & -6046 & Nord-Est (ROU) & 0.002 & -2319 \\
\hline $\begin{array}{l}\text { Wielkopolska and Śląsk } \\
(\mathrm{POL})\end{array}$ & 0.087 & $\begin{array}{l}\text { Makedonia-Thraki } \\
(\text { ELL) }\end{array}$ & 0.59 & -16186 & Centru (ROU) & 0.001 & -2430 \\
\hline $\begin{array}{l}\text { Schleswig-Holstein } \\
(\mathrm{DEU})\end{array}$ & 0.086 & Sud-Est (ROU) & 0.56 & -11713 & Vest (ROU) & 0 & -3939 \\
\hline Saarland (DEU) & 0.086 & Nord-Vest (ROU) & 0.52 & -8832 & $\begin{array}{l}\text { Sud-Vest Oltenia } \\
\text { (ROU) }\end{array}$ & 0 & -4409 \\
\hline Severoiztochen (BGR) & 0.082 & Sud-Muntenia (ROU) & 0.46 & -14905 & Sud-Muntenia (ROU) & 0 & -4462 \\
\hline Sachsen (DEU) & 0.082 & Vest (ROU) & 0.43 & -14391 & Bucureşti-Ilfov (ROU) & 0 & -5737 \\
\hline Etelä-Suomi (FIN) & 0.078 & $\begin{array}{l}\text { Sud-Vest-Oltenia } \\
\text { (ROU) }\end{array}$ & 0.34 & -14938 & Malta (MLT) & 0 & -11094 \\
\hline Pohjanmaa (FIN) & 0.072 & $\begin{array}{l}\text { Comunidad Valenciana } \\
\text { (ESP) }\end{array}$ & 0.18 & -248037 & Scotland (UK) & 0 & -15125 \\
\hline
\end{tabular}

* Bolded regions are duplicated at least in two rankings.

Source: own calculation based on EUFADN. 
can be observed in the group of farms with the highest ESV according to the eco-efficiency criterion. It is also very likely that eco-effectiveness goes in the line with the low environmental burden measure, except some cases mentioned above. Thus, we should ask the question of which concept of environmental sustainability we are striving for within CAP principles?

\section{CONCLUSIONS}

The aim of the article was to compare three different approaches to measuring sustainability of agriculture in terms of the methodology as well as the results of empirical study carried out on the sample of EU regions. The study indicate a fundamental problem: the environmental sustainability of European farms differs depending on the criterion we apply. If we compare the synthetic measure of the environment pressure with I-O approaches we have to concede the superiority to the latter. We shall admit that there are trade-offs in CAP which consist of compensating strain on the natural environment with... and here you are the principal question: with production or public goods? We do not attempt to answer this question now but we hope the article will inspire a broader discussion on this issue. If we assume the eco-efficiency criterion, it is the highest where the adopted polluting input produces relatively the highest effect in the form of the total output. When it comes to the eco-effectiveness criterion, however, there is a different priority - not production, but the share of environmental subsidies, assuming they follow a provision of environmental public goods, which make up for the polluting capital used by farms.

\section{Acknowledgements}

This article is founded by the National Science Centre in Poland (grant 2016/21/B/HS4/00653).

\section{REFERENCES}

1. Berre, D., Vayssičres, J., Boussemart, J-P., Leleu, H., Tillard, E., Lecomte, P. (2015). A methodology to explore the determinants of eco-efficiency by com- bining an agronomic whole-farm simulation model and efficient frontier. Environmental Modelling \& Software, 71, pp. 46-59. http://dx.doi.org/10.1016/ j.envsoft.2015.05.008

2. Bonfiglio, A., Arzeni, A., Bodini, A. (2017). Assessing eco-efficiency of arable farms in rural areas. Agricultural Systems, 151, pp. 114-125.

3. Burja, C., Burja, V. (2016). The economic farm size and sustainable value. Disparities between Romania and the EU states. Annales Universitatis Apulensis. Oeconomica, 17 (1), pp. 82-89.

4. Czyżewski, B., Kryszak, Ł. (2017). Kondycja finansowa gospodarstw rolnych w regionach FADN Unii Europejskiej i jej związek z produktywnością czynników wytwórczych [The financial situation of agricultural holdings in the FADN regions of the European Union and their relationship to the productivity of production factors]. Roczniki Naukowe Ekonomii Rolnictwa i Rozwoju Obszarów Wiejskich, 104 (3), pp. 7-19. DOI: 10.22630/RNR.2017.104.3.17

5. Czyżewski, B., Matuszczak, A. (2016). A new land rent theory for sustainable agriculture. Land Use Policy, 55, pp. 222-229. http://dx.doi.org/10.1016/ j.landusepol.2016.04.002

6. Czyżewski, B., Matuszczak, A. (2018). Towards measuring political rents in agriculture: case studies of different agrarian structures in the EU. Agricultural Economics (AGRICECON). DOI: 10.17221/286/2016AGRICECON.

7. Czyżewski, B., Matuszczak, A., Muntean, A. (2018). Influence of agricultural policy on the environmental sustainability of European farming. Journal of Environmental Protection and Ecology, 19 (1), pp. 426-434.

8. Czyżewski, B., Przekota, G., Poczta-Wajda, A. (2017). The incidence of agricultural policy on the land market in Poland: Two-dimensional and multilevel analysis. Land Use Policy, 63, pp. 174-185. http://dx.doi. org/10.1016/j.landusepol.2017.01.016

9. European Commission (2000). The environmental impact of dairy production in the EU: practical options for the improvement of the environment impact. Final report. Retrieved form: http://ec.europa.eu/environment/ agriculture/pdf/dairy.pdf [Accessed 07.04.2017].

10. Figge, F., Hahn, T. (2005). The Cost of Sustainability Capital and the Creation of Sustainable Value by Companies. Journal of Industrial Ecology, 9, pp. 47-58.

11. Gadanakis, Y., Bennett, R., Park, J., Areal, F.J. (2015). Evaluating the sustainable intensification of arable farms. Journal of Environmental Management, 150, pp. 288-298. http://dx.doi.org/10.1016/j.jenvman.2014.10.005 
12. Gómez-Limón, J.A., Picazo-Tadeo, A.J., Beltrán-Esteve, M. (2012). Assessing eco-efficiency with directional distance functions. European Journal of Operational Research, 220 (3), pp. 798-809.

13. Hayati, D., Karami, E. (1996). A proposed scale to measure sustainability at farm level in socio-economic studies. Paper presented at first agricultural economic conference of Iran. Zabol, Iran 05-07.05.1996.

14. Illge, L., Hahn, T., Figge, F. (2008). Applying and Extending the Sustainable Value Method to Agriculture - an Overview. In: 12th Congress of the European Association of Agricultural Economists - EAAE, Ghent.

15. Kates, R., Parris T.M., Leiserowitz A.A. (2005). What is sustainable development? Environment, 47 (3), pp. 9-21.

16. Latruffe, L., Diazabakana, A. Bockstaller, C. Desjeux, Y., Finn, J., Kelly, E., Ryan, M., Uthes, S. (2016). Measurement of sustainability in agriculture: a review of indicators. Studies in Agricultural Economics, 118, pp. 123-130.

17. OECD (1998). Eco-Efficiency. OECD Publishing, Paris.

18. OECD (2001). Environmental Indicators for Agriculture: Methods and Results. Organisation for Economic Cooperation and Development. OECD Publishing, Paris.

19. Pérez Urdiales, M., Lansink, A.O., Wall, A. (2016). Eco-efficiency among dairy farmers: the importance of socio-economic characteristics and farmer attitudes. Environmental and Resource Economics, 64, pp. 559-574. http://dx.doi.org/10.1007/s10640-015-9885-1
20. Picazo-Tadeo, A.J., Gómez-Limón, J.A., Reig-Martínez, E. (2011). Assessing farming eco-efficiency: a data envelopment analysis approach. Journal of Environmental Management, 92, pp. 1154-1164. http://dx.doi. org/10.1016/j.jenvman.2010.11.025.

21. Poczta-Wajda, A., Poczta, J. (2016). The role of natural conditions in qualified agritourism - case of Poland. Agricultural Economics - Zemedelska Ekonomika, 62 (4), pp. 167-180.

22. Reytar, K., Hanson, C., Henninger, N. (2017). Indicators of Sustainable Agriculture: a Scoping Analysis. Working Paper, Installment 6 of Creating a Sustainable Food Future. World Resources Institute, Washington, DC.

23. Saltiel, J., Baunder, J.W., Palakovich, S. (1994). Adoption of sustainable agricultural practices: diffusion, farm structure and profitability. Rural Social, 59 (2), pp. 333-347.

24. Van Passel, S., Nevens, F., Mathijs, E., Van Huylenbroeck, G. (2007). Measuring farm sustainability and explaining differences in sustainable efficiency. Ecological Economics, 62 (1), pp. 149-161.

25. Zegar, J.S. (2012). Współczesne wyzwania rolnictwa [The modern challenges facing agriculture]. Wydawnictwo Naukowe PWN, Warszawa.

26. Zhen, L., Routray, J.K. (2003). Operational indicators for measuring agricultural sustainability in developing countries. Environmental Management, 32 (1), pp. 34-46. 